\title{
Calculation of salt basin depth using fluid inclusions in halite from the Ordovician Ordos Basin in China
}

\author{
Anatoliy R. GALAMAY ${ }^{1}$, Fanwei MENG ${ }^{2, *}$, Krzysztof BUKOWSKI $^{3, *}$, \\ Aleksandr LYUBCHAK ${ }^{1}$, Yongsheng ZHANG ${ }^{4}$ and Pei $\mathrm{NI}^{5}$ \\ 1 National Academy of Sciences of Ukraine, Institute of Geology and Geochemistry of Combustible Minerals, Naukowa 3A, \\ 79-060 Lviv, Ukraine \\ 2 Chinese Academy of Sciences, State Key Laboratory of Palaeobiology and Stratigraphy, Nanjing Institute of Geology and \\ Palaeontology and Center for Excellence in Life and Paleoenvironment, 39 East Beijing Road, 210008 Nanjing, China \\ 3 AGH University of Science and Technology, Faculty of Geology, Geophysics and Environmental Protection, Al. \\ Mickiewicza 30, 30-059 Kraków, Poland \\ 4 Chinese Academy of Geological Sciences, Institute of Mineral Resources, Beijing 100037, China \\ 5 Nanjing University, State Key Laboratory for Mineral Deposits Research, Institute of Geo-Fluid Research, School of Earth \\ Sciences and Engineering, Nanjing, 210093, China
}

Galamay, A.R., Meng, F., Bukowski, K., Lyubchak, A., Zhang, Y., Ni, P., 2019. Calculation of salt basin depth using fluid inclusions in halite from the Ordovician Ordos Basin in China. Geological Quarterly, 63 (3): 619-628, doi: 10.7306/gq.1490

Associate Editor - Jacek Szczepański

During the Middle Ordovician, the salt deposits of the Majiagou Formation of the Ordos Basin in North China formed, the halite including various genetic types of fluid inclusion. In this study, fit-testing of primary inclusions was performed to reconstruct the physical and chemical conditions during original halite sedimentation. During the post-sedimentation stage, salt was subjected to elevated temperatures $\left(62-70^{\circ} \mathrm{C}\right)$ and pressures of tens of megapascals. From these measurements and mathematical calculations, the gas pressure was identified in the primary fluid inclusions, which allowed us to estimate that the brine column thickness in the salt basin was approximately $40 \mathrm{~m}$.

Key words: halite, gas-liquid inclusion, brine depth, Ordos Basin, Ordovician evaporate.

\section{INTRODUCTION}

The determination of crystallization conditions in ancient salt basins plays an important role in palaeogeographic reconstructions, and relevant methods have been developed since the middle of the 20th century (Borchert and Muir, 1964). However, there are no reliable criteria according to which a basin's depth can be directly determined (Ivanov and Voronova, 1972; Babel and Schreiber, 2014). Supporters of the deep water hypothesis of evaporite basins (i.e., that they were deposited at hundreds of metres of water depth) have built their assumptions on the immensity of immensity of some ancient basins and the considerable thicknesses of salt deposits within such basins (e.g., Schmalz, 1969). On the other hand, the supporters of a

\footnotetext{
* Corresponding authors, e-mail: Fanwei Meng (fwmeng@nigpas.ac.cn) and Krzysztof Bukowski (buk@agh.edu.pl) Received: February 22, 2019; accepted: July 19, 2019; first published online: September 30, 2019
}

shallow water hypothesis (i.e., that the salts were deposited in water up to $15 \mathrm{~m}$ deep) (e.g., Strakhov, 1967; Valyashko, 1962) have interpreted the considerable thicknesses of salts as a function of structural-tectonic conditions in which salt accumulated by analogy to present-day "salina" basins (Babel, 2007).

During the late 1980's, scientists developed a method for calculating the depths of salt basins, starting from the gas $\left(\mathrm{CH}_{4}\right.$ $+\mathrm{N}_{2}$ ) saturation of brines in the primary, single-phase fluid inclusions within halite (Petrichenko, 1988). According to data on pressure, temperature and geochemistry, the thicknesses of the brine columns in ancient salt basins ranged from 6-450 m during the halite sedimentation stage, and from less than 8 up to $50 \mathrm{~m}$ during the stage that preceded the crystallization of potassium salts (Petrichenko, 1988). However, even recently the following statements are often found in the literature: "very deepwater", "deepwater", "relatively deep water", and "shallow water", without the depth having actually been determined in the course of a given study.

The Ordos Basin represents one of the largest oil and gas production regions in China and has therefore been the focus of many previous studies (e.g., Feng et al., 1998; Wang and Al-Aasm, 2002; Yu et al., 2017). The recent discovery of a new 
tight carbonate gas exploration field, within the Middle Ordovician Majiagou Formation, in the eastern part of the basin (Zhang et al., 2018) has contributed to the reevaluation of the reservoir's potential. The brine depth during Ordovician evaporitic sedimentation in the Ordos Basin has been the subject of controversy and was discussed by Xue (1986), Zhang et al. (1991), and Bao et al. (2004). Until recently, it was accepted that the Ordovician Majiagou Formation developed as a gently inclined carbonate platform in a very shallow epicontinental sea, and that evaporites occurred in a restricted, shallow, and hypersaline environment (Feng et al., 1998; Wang and AlAasm, 2002; Yang et al., 2005; Li et al., 2011). Zhang et al. (1991) concluded that at the beginning of halite precipitation, the salt were formed within a deep basin, and the next evaporitic basin gradually experienced the shallowing of the basin to a sabkha environment by the end of deposition. Our case study calculates the depth of the Ordos Basin during salt sedimentation by evaluating the size of the gas phase of the primary, gas-liquid inclusions within halite, immediately after the inclusions were depressurized. Such information is important for understanding salt sedimentation and the environmental evolution of the Ordos Basin.

\section{GEOLOGICAL SETTING}

The Ordos Basin, also known as the Shaanxi-Gansu-Ningxia Basin, is the second largest sedimentary basin in China, with a surface area of $\sim 250,000 \mathrm{~km}^{2}$. Geologically, the Ordos Basin is a platform-type basin, located within the western sec- tion of the North China Massif (Fig. 1). The basin has experienced several evolutionary stages since the basement was formed, including Archean-Proterozoic basement formation in the continental accretion stage, Early Paleozoic terrigenous shallow marine conditions in the passive continental margin stage, a Caledonian-Hercynian regional uplifting stage, and a Late Paleozoic intra-continental depression stage of the North China Craton. Since the Mesozoic, the basin began to shrink and underwent denudation. During the Cenozoic, strong structural zones developed along the basin margin, accompanied by the intrusion and eruption of igneous rocks (Yu et al., 2017). The total thickness of the sedimentary succession in the Ordos Basin is estimated to be approximately $5-10 \mathrm{~km}$. Hydrocarbons are mainly produced from the Triassic, Jurassic, and Ordovician systems.

In the Early Paleozoic, when the Northern China Block moved to the 20th parallel of the southern hemisphere (Scotese, 2014), continental lowlands were extensively flooded, and a shallow epeiric sea existed during Ordovician times. On the margins of that inland sea, several ancient landmasses provided barriers to the flow of sea water between the intracratonic platform and the open sea (Chen et al., 2019). Consequently, carbonate rocks interbedded with evaporites were formed within shallow platform environments. In the Ordos Basin, the Ordovician succession is usually $600-800 \mathrm{~m}$ thick, and it mainly consists of carbonates (dolomite and limestone), with interbedded anhydrite and halite.

The main evaporite-bearing unit in the Ordos Basin is found within the Majiagou Formation. Sections 1, 3, and 5 of the Majiagou Formation are mainly evaporite successions, while sections 2, 4, and 6 are dominantly carbonate successions

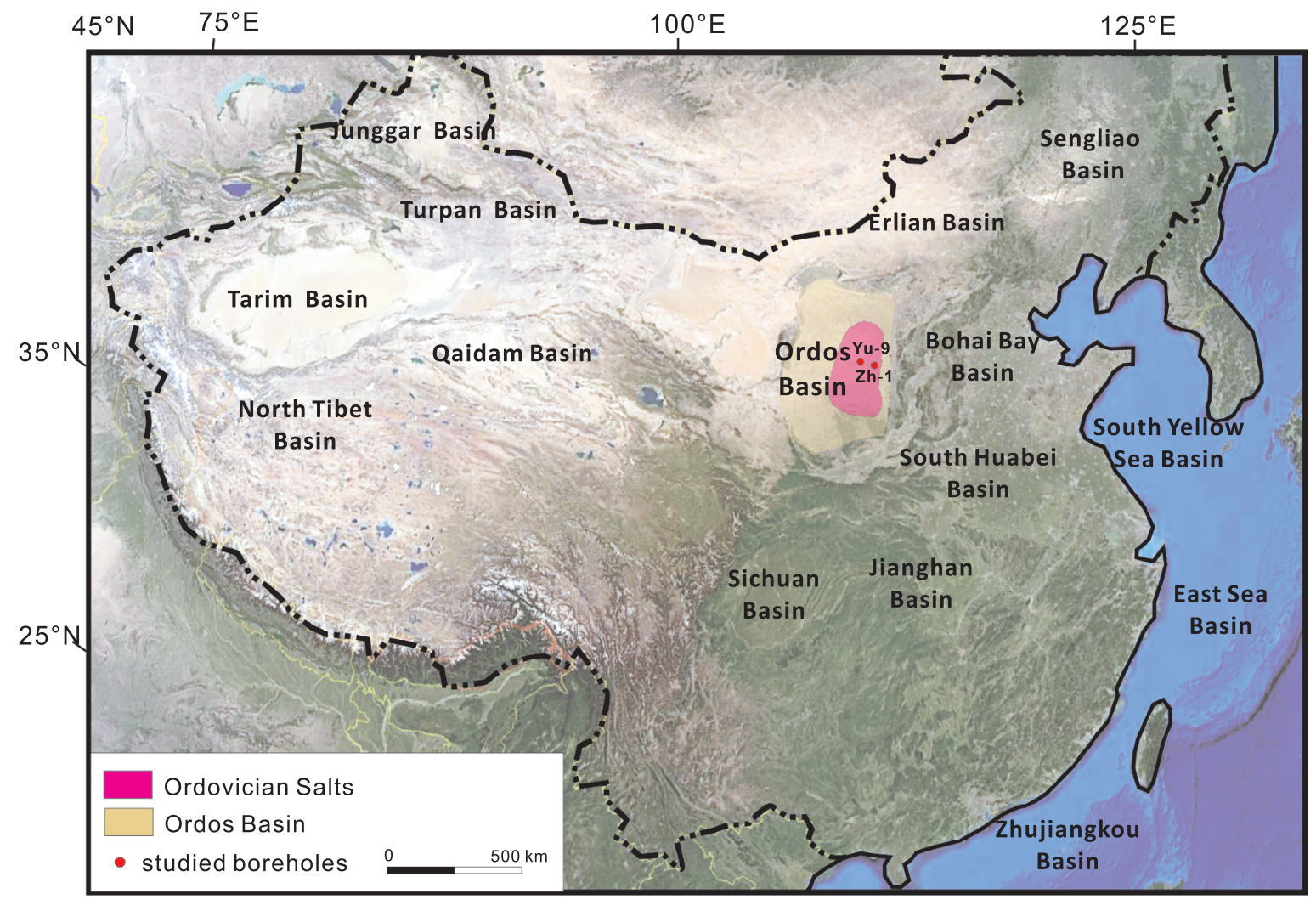

Fig. 1. Location of the Ordos Basin in China

The most important petroliferous basins are shown on the map 
(Bao et al., 2004; Meng et al., 2018, 2019). Carbonate isotope stratigraphy has indicated that the Majiagou Formation formed during the Middle Ordovician (Meng et al., 2019). Evaporite deposits in this unit are represented by frequent alternations between fine silty dolomite, halite, and anhydrite (Fig. 2). They are both underlain and overlain by marine carbonate deposits, including limestones and dolomites.

The evaporites in the Ordovician Majiagou Formation are platform deposits formed in lagoons that received the restricted seepage of external marine waters. In those lagoons, the brine surfaces responded to slow, low-amplitude 4th-order eustatic rises and falls in sea levels, and the resulting bedded evaporites were interbedded with normal marine platform carbonates (Chen et al., 2019). Currently, the evaporitic sediments of the Majiagou Formation are recognized in boreholes at depths $>2 \mathrm{~km}$, in the eastern and central sections of the Ordos Basin (Figs. 1 and 2).

\section{FLUID INCLUSIONS IN HALITE}

The determination of fluid inclusions in halite, which is necessary to define genetic type, is a complex task as such inclusions occur within the sedimentary textures of the halite in the Majiagou Formation.

\section{PRIMARY FLUID INCLUSIONS}

The crystallization mechanism of halite at the bottom of modern evaporite basins is well-known (e.g., Valyashko, 1952; Lowenstein and Hardie, 1985; Babel and Schreiber, 2014). Modern halite crystals featuring chevron textures represent the same mechanism of origin as those formed in ancient salt basins (Kovalevych et al., 2009; Kovalevych and Vovnyuk, 2010; Galamay and Bukowski, 2011). The structural features of chevron halite are associated with a zonal distribution of microinclusions, parallel to the crystal growth facets. Two types of mineral inclusion distribution can be distinguished in halite, those with non-systematic and those with rhythmic zonation (Petrichenko, 1988). In halite with rhythmic zonation, the width of the rhythms (i.e., the zone with inclusions + the zone without inclusions) indicates the daily rates of halite growth. Cloudy-white zones with inclusions formed during rapid crystallization, while transparent ones without inclusions formed during slow crystallization. All primary inclusions in each growth zone have identical values of pressure and temperature (P-T) parameters and the same chemical composition of their respective brines.

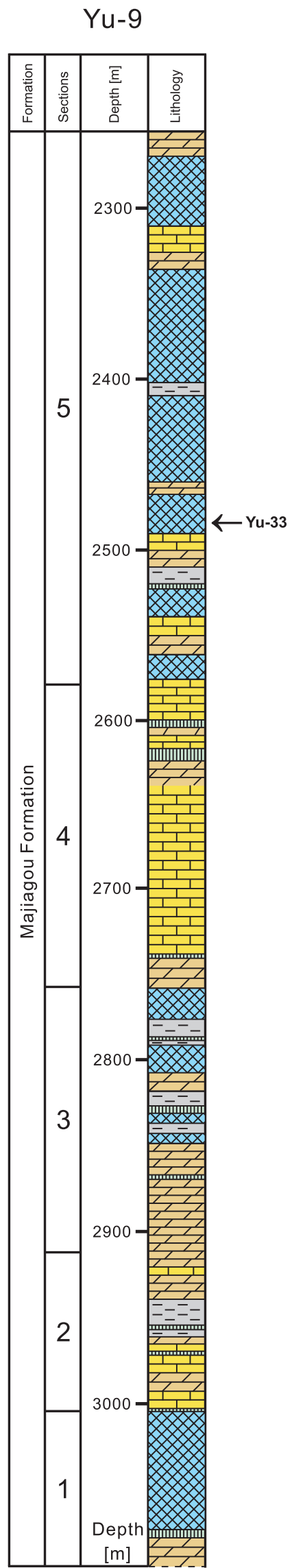

Zhenjia-1

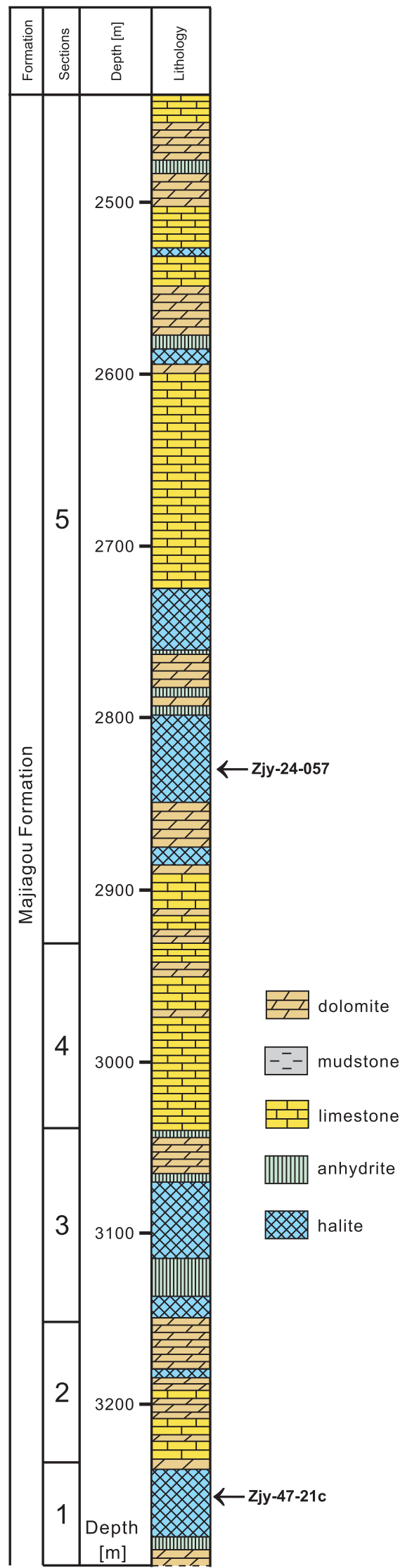

Fig. 2. Lithological column responses for the Yu-9 and Zhengjia-1 boreholes (after Meng et al., 2018) with sampling sites 
SECONDARY FLUID INCLUSIONS IN CHEVRON AND TRANSPARENT RECRYSTALLIZED HALITE

In addition to primary inclusions, secondary inclusions of various generations have been detected within sedimentary and transparent post-sedimentation halite, and the latter are located either non-systematically or along resistive fractures. It is possible to nominally distinguish the following groups of inclusions as representing early and late diagenesis: small and large sizes, regular and irregular shapes, single-phase (liquid) and gas-liquid inclusions, respectively (Galamay et al., 2004).

\section{HALITE GAS-LIQUID INCLUSIONS}

Since chevron halite crystallizes at the bottom of salt basins, the brine column thickness increases with higher hydrostatic pressures and correspondingly, the gas saturation of the brine inclusions is also higher. Based on observations of gas pressures in primary fluid inclusions of halite, we can estimate the depth of the ancient salt basin. Gas microinclusions (e.g., microoccluded gases) in the rock salt mass are widespread, occurring in the fluid inclusions of halite in a dissolved state. If the halite crystallized at temperatures above $42^{\circ} \mathrm{C}$, or if it was subject to overheating in the range of $50-110^{\circ} \mathrm{C}$ during post-sedimentation transformation, gas would also have been present in fluid inclusions in the form of separate phases (Petrichenko, 1973; Acros and Ayora, 1997).

In the primary fluid inclusions found in Phanerozoic halite deposits, the following components are present: nitrogen, carbon dioxide, methane, and hydrogen, generally in the order of: $\mathrm{N}_{2}>\mathrm{CO}_{2}>\mathrm{CH}_{4}>\mathrm{H}_{2}$. Three types of inclusion are distinguished by gas components: one with substantial nitrogen $\left(\mathrm{N}_{2}>\mathrm{CO}_{2}>\mathrm{CH}_{4}\right)$, one with substantial methane $\left(\mathrm{CH}_{4}>\mathrm{N}_{2}>\mathrm{CO}_{2}\right)$, and one with nitrogen-methane $\left(\mathrm{N}_{2} \geq \mathrm{CH}_{4}>\mathrm{CO}_{2}\right)$ (Litvinyuk, 2007). The methane content prevails over nitrogen in the fluid inclusions of halite, as methane is drawn from the salt-bearing layers, rich in organic matter (Galamay and Baranenko, 2004; Kovalevych et al., 2006).

Previous studies on the composition of gas in the brines of primary and early diagenetic inclusions within halite during various time periods of the Phanerozoic (Litvinyuk, 2007; Więcław et al., 2008), particularly during the Ordovician (Kovalevych et al., 2006), show that the sum of $\mathrm{N}_{2}+\mathrm{CH}_{4}$ in the inclusions amounts to $>70 \%$, with $\mathrm{CO}_{2}$ comprising $0-23.8 \%$ $($ mean $=7.1 \%)$. The hydrogen data in the gas mixture are not informative due to the ability of hydrogen to diffuse freely through the crystal structure of the mineral. The sources of these components in the bottom brine of the salt basin were biochemical processes and the atmosphere (Weiss, 1969; Kovalevych et al., 2008). The absence of oxygen in the gas mixture is associated with oxygen consumption during chemical and biochemical oxidation.

\section{MATERIALS AND METHODS}

During our case study, we observed 2 samples collected from boreholes Yu-9 and 10 samples from borehole Zhengjia-1, located in the middle section of the Ordos Basin (Figs. 1 and 2). The samples included mainly recrystallized rock salts, with transparent halite crystals ranging from $1-1.5 \mathrm{~cm}$ in size, frequently with inclusions of greenish-black clay particles. However, only in three samples have we documented relics of sedimentary halite (i.e., in boreholes Zjy-47-21c, Zjy-24-057 and Yu-33; Fig. 2).
Halite plates (1-2 $\mathrm{mm}$ thick), cut parallel to the cleavage surface, were polished to determine the homogenization temperatures of two-phase (gas-liquid) and three-phase (gas-liquid-daughter crystal) inclusions. Halite plates were slowly heated to the temperature of inclusion homogenization in a special thermo-chamber made by Kalyuzhny (1982). The heating rate did not exceed $0.2^{\circ} \mathrm{C} / \mathrm{min}$. when it approached the homogenization temperature. The error in measuring the homogenization temperature is $\sim 1^{\circ} \mathrm{C}$. Since the fluid inclusions observed contained not only gas bubbles and sylvite daughter crystals, but also clay particles and xenogenic crystals, we mainly determined the homogenization temperature of the inclusions in the presence of such insoluble phases.

To determine the internal pressure within the inclusions, halite plates with primary gas-liquid inclusions were slowly dissolved in glycerin, with a minimum amount of water. Parameters such as the diameter of the gas phase before and after depressurization of the inclusions were measured under the optical microscope. The measurements were made with a Huygens eyepiece, equipped with a fine-adjustment screw and installed in the field of view at the scale. Based on mathematical calculations and the graphical structure, we identified the absolute pressure in the primary fluid inclusions.

\section{RESULTS AND INTERPRETATIONS}

\section{FLUID INCLUSIONS IN HALITE}

Primary chevron structures of the Majiagou Formation are characterized by non-systematic zonation with gas-liquid inclusions (Fig. 3C, D).

In some inclusions, small anisotropic crystals of anhydrite were found. The inclusions are cubic, with the lengths of the edges of cubes varying from a few micrometres to $30 \mu \mathrm{m}$ (Fig. 3). In Sample Zjy-47-21c, inclusions 80-100 $\mu \mathrm{m}$ in size are present (Fig. 3A, B). The internal pressure of the inclusions is slightly higher than the normal atmospheric pressure which was recorded at the time of collection. Brines are present until the middle stage of halite deposition, and they characterize the sea water as a Na-K-Mg-Ca-Cl (Ca-rich) type (Meng et al., 2018). In our study three groups of secondary inclusions were distinguished:

1. Early diagenetic gas-liquid inclusions up to $1 \mathrm{~mm}$ in size, cubic or close to cubic. Isotropic sylvite daughter crystals were found in the inclusions. The presence of $\mathrm{K}$ salt minerals indicated a high concentration of brines during potassium salt precipitation (Meng et al., 2018). The inclusions were arranged non-systematically in the chevron halite and on the periphery of the chevrons (Fig. $4 \mathrm{~A}-\mathrm{C}$ ). The internal pressure was close to the pressure in the primary inclusions. Evidence of inclusion cracking was not recorded.

2. Anomalously large, late diagenetic, gas-liquid inclusions up to $2-3 \mathrm{~mm}$ across and irregular in shape. These inclusions often contained numerous anisotropic, small crystals of anhydrite and black clay particles. The inclusions were located in transparent recrystallized halite (Fig. 4D). The internal pressure in these inclusions was higher than that in the primary inclusions. Aureoles of small fluid inclusions in resistive fractures were found around large inclusions.

3. Late diagenetic single-phase (liquid) and gas-liquid inclusions that are cubic (size: $50-200 \mu \mathrm{m}$ ). The inclusions were located in secant cracks in halite (Fig. 4E, F). 

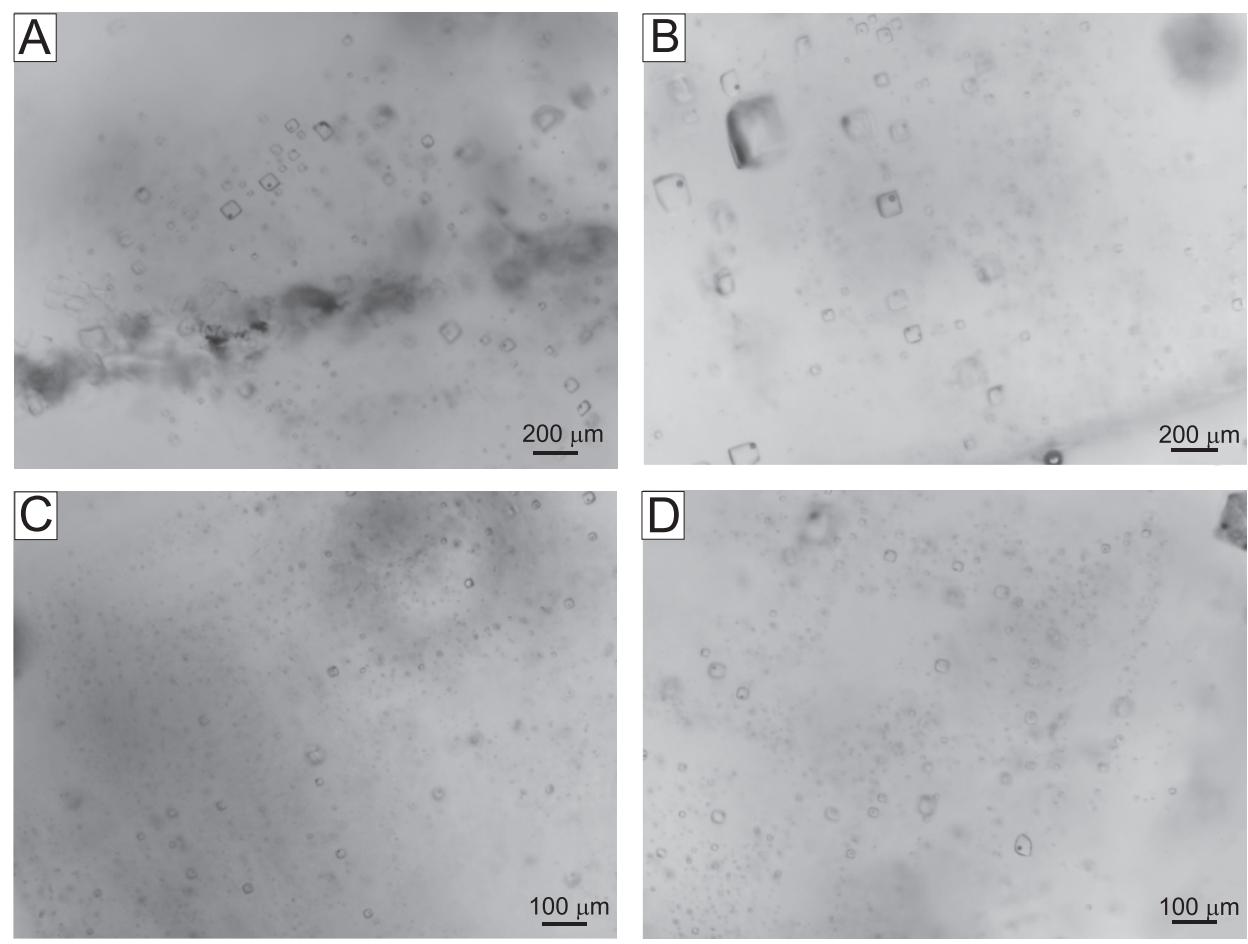

Fig. 3. Zonation of sedimentary halite chevron for (A, B) sample Zjy-47-21c, (C) sample Zjy-24-057, and (D) sample Yu-33

Internal pressure there was close to the normal atmospheric pressure. The brine composition was characterized by reduced values of all major ions relative to sedimentation and early diagenetic types, and the type of brine did not change.

The homogenization temperatures of the primary and early diagenetic fluid inclusions of the Majiagou Formation were similar, and sylvite crystals in the early diagenetic inclusions completely dissolved at $46-54^{\circ} \mathrm{C}$ (Table 1). Anomalously large, gas-liquid, late diagenetic inclusions were not homogenized. The temperature of homogenization of the late diagenetic gas-liquid inclusions, located in the intersected cracks, was recorded in the range of $27-30^{\circ} \mathrm{C}$.

The salt deposits of Majiagou Formation formed under various P-T conditions. The sedimentation temperature was not determined due to overheating at temperatures of $62-70^{\circ} \mathrm{C}$ during one of the post-sedimentation stages. Large secondary fluid inclusions of recrystallized halite were depressurized under such conditions and overfilled at an elevated pressure. The formation of late-diagenetic inclusions, representing low pressure, was the result of the cleaving and stretching of individual salt blocks during tectonic processes (Matukhin et al., 1985). The preservational integrity of the primary fluid inclusions in the Majiagou Fmormation halite indicates that the chemical compositions of these inclusions are the same, and that they are different in comparison to those of the secondary fluid inclusions (Meng et al., 2018).

\section{INTERNAL PRESSURE WITHIN FLUID INCLUSIONS}

The primary inclusions of sedimentation halite, observed in the majority of salt-bearing formations, were characterized by their pressures being close to the normal atmospheric pressure. Some authors mentioned a pressure increase in the primary single-phase fluid inclusions (Moscowskiy, 1983) and in the primary fluid inclusions containing a gas phase (Litvinyuk, 2007). In the Majiagou halite (Zjy-47-21c), we investigated gas-liquid primary inclusions (Fig. 3 ), with sizes ranging from 20-45 $\mu \mathrm{m}$. Immediately after the inclusions had depressurized, the gas phase increased by 1.8-2 times in diameter (Table 2).

If all of the gas was in a different phase, the initial pressure (before inclusion depressurization) was equal to the cubic degree of the absolute increase of the gas phase radius, although in our case, only a certain portion of gas captured during crystallization was contained in the gas bubble. Taking into account the fact that the solubility of gas components increases with increasing pressure and decreasing temperature, we derived the following equation:

$$
\frac{P_{1}}{P_{0}}=\frac{P_{\max }}{P_{0}}-k_{2} \frac{R T}{P_{0}} \sum_{n=1}^{n} V_{i}\left[r_{\left(P_{1}\right)}-r_{\left(P_{0}\right)}\right]_{i}
$$

where: $P_{0}=101325[\mathrm{~Pa}]$ - standard pressure (after inclusion depressurization), $P_{1}[\mathrm{~Pa}]$ - initial pressure (before inclusion depressurization), and $P_{\max }[\mathrm{Pa}]$ - maximum possible pressure in the inclusion (without taking into account the pressure of gas dissolved before inclusion depressurization). Additionally, $R=8.31441[\mathrm{~J} / \mathrm{K}$ $\mathrm{mol}]$ is taken as the universal gas constant, $T=291[\mathrm{~K}]\left(18^{\circ} \mathrm{C}\right)$ is the test temperature, $r\left(p_{1}\right)$ and $r\left(p_{0}\right)$ are the solubilities of each gas component $(i)$ at the initial and standard pressures, respectively, in $\mathrm{mol} / \mathrm{m}^{3}$. Finally, $n$-amount of components in a gas mixture, $\mathrm{i}_{\mathrm{i}}-\mathrm{mo}-$ lar part of the gas components, and $k_{2}$ - ratio of the brine inclusion volume to the initial volume of the gas bubble, such that:

$$
k_{2}=\frac{3}{4 \cdot \pi} \cdot\left(\frac{L}{R_{1}}\right)^{3}-1
$$



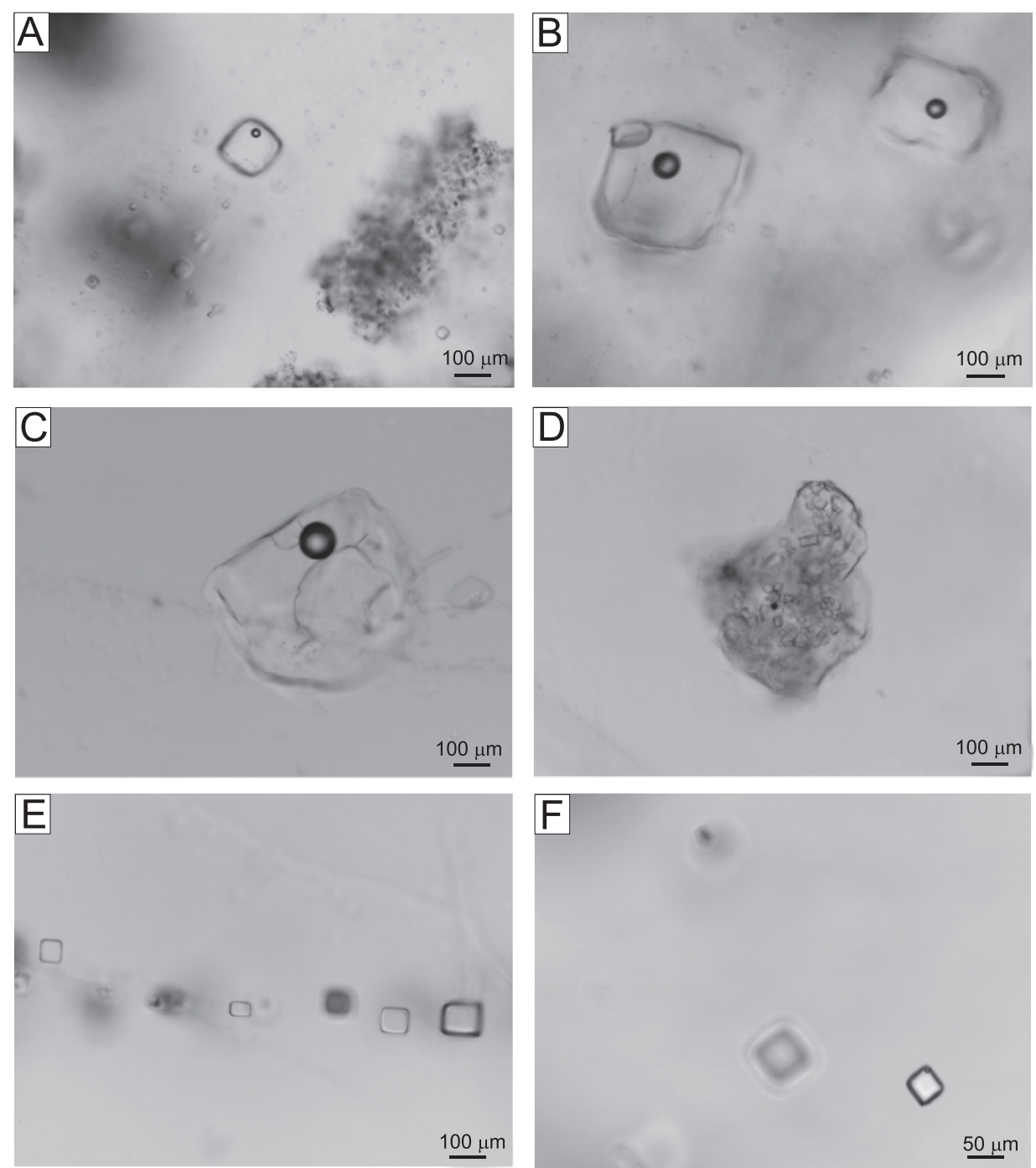

Fig. 4. Early diagenetic inclusions with a sylvite daughter crystal at the margin of halite zonation in (A) sample Zjy-24-057 and (B, C) sample Yu-33; late diagenetic inclusions in transparent recrystallized halite in (D) sample Yu-33; late diagenetic single-phase fluid inclusions (E), and two-phase (gas-liquid) inclusions (F) in the intersected fractures of halite in sample $\mathrm{Yu}-33$

where: $L$ - length of the inclusion edge and $R_{1}$ - gas phase radius before inclusion depressurization.

Taking into account the change in pressure above a curved surface (Zhukhovitsky and Shvartsman, 1968), the maximum possible pressure is expressed by the following equation:

$$
\frac{p_{\max }}{P_{0}}=k_{1}^{3}+\frac{2 \cdot \sigma}{R_{1} \cdot P_{0}} \cdot\left(k_{1}^{2}-1\right)
$$

where: $\sigma$ - coefficient of the surface tension for highly concentrated solutions. Within the range of $0.073-0.093[\mathrm{H} / \mathrm{m}]$, this value does not significantly affect the accuracy of calculations; we assumed a value of $\sigma=0.083[\mathrm{H} / \mathrm{m}]$. The coefficient of the linear increase in the gas phase $\left(k_{1}\right)$ was defined as the ratio of the standard $\left(R_{0}\right)$ to the initial $\left(R_{1}\right)$ radius of the surface curvature:

$$
k_{1}=\frac{R_{0}}{R_{1}}
$$

Since an unknown value $\left(P_{1}\right)$ appears on the left and right sides of Equation [1], it is better to perform those calculations using a graphic method, which requires a minimum number of calculations. Equation [1] is the linear function of $P_{1} / P_{0}$, from $r_{(\mathrm{p} 1)}$ $-r_{(\mathrm{p} 0)}$, where the expression before the square brackets is the coefficient of the angular inclination of the solid lines, and $P_{\text {max }} / P_{0}$ is the value on the $P_{1} / P_{0}$ axis that determines their initial points (Fig. 5). The dispersion of solid lines is associated with measurement errors. The intersection points of the long broken lines and solid lines in Figure 5 determine the partial (reduced to standard) gas pressure (Table 3 ).

The determination of the compositions of gas mixtures in the primary inclusions of the Majiagou halite was difficult since the late-diagenetic inclusions greatly prevailed in volume. However, the gas dissolved in the brines of primary inclusions of halite contained predominantly $\mathrm{N}_{2}$ and $\mathrm{CH}_{4}$. For that reason, we calculated the pressure values for gas mixtures that varied in the compositions occurring in the primary inclusions in the halite of Phanerozoic deposits (Tables 4 and 5). One can conclude from these calculations, regardless of the composition of the 
Table 1

Homogenization temperatures of the primary and secondary fluid inclusions, with gas bubbles and sylvite daughter crystals

\begin{tabular}{|c|c|c|c|}
\hline \multirow{2}{*}{ Fluid inclusion } & \multirow{2}{*}{$\begin{array}{c}\text { Size } \\
{[\mu \mathrm{m}]}\end{array}$} & $\begin{array}{c}\text { Homogenization } \\
\left.\text { temperature [ }{ }^{\circ} \mathrm{C}\right]\end{array}$ \\
\cline { 2 - 4 } & $\begin{array}{c}\text { Gas } \\
\text { bubble }\end{array}$ & Sylvite \\
\hline \multicolumn{4}{|c|}{ Sample Yu-33 } \\
\hline primary & 30 & 66 & - \\
\hline$-/ /-$ & 50 & 66 & - \\
\hline early diagenetic & $300 \times 200$ & 64 & 50 \\
\hline$-/ /-$ & 200 & 70 & 46 \\
\hline \multicolumn{4}{|c|}{ Sample Zjy-24-057 } \\
\hline primary & 30 & 65 & - \\
\hline$-/ /-$ & 30 & 62 & - \\
\hline early diagenetic & 70 & 64 & 53 \\
\hline -//- & $250 \times 180$ & 66 & 54 \\
\hline \multicolumn{4}{|c|}{ Sample Zjy-47-21c } \\
\hline
\end{tabular}

Lines indicate that data were unavailable

Table 2

Measured parameters: cube edge of the inclusions $(L)$; gas-phase radii before $\left(R_{1}\right)$ and after $\left(R_{0}\right)$ inclusion depressurization

\begin{tabular}{|c|c|c|c|c|c|}
\hline \multirow{2}{*}{$\begin{array}{c}\text { Inclusion } \\
\text { No. }\end{array}$} & \multicolumn{2}{|c|}{$\begin{array}{c}\text { Inclusion and gas } \\
\text { phase parameters } \\
{[\mu \mathrm{m}]}\end{array}$} & \multicolumn{3}{c|}{ Coefficients } \\
\cline { 2 - 6 } & $L$ & $R_{1}$ & $R_{0}$ & $k_{2} \cdot \frac{R \cdot T}{P_{0}}$ & $P_{\text {max }} / P_{0}$ \\
\hline 1 & 25.8 & 4.5 & 8.6 & 0.605 & 7.83 \\
\hline 2 & 17.4 & 3.15 & 6.0 & 0.528 & 8.11 \\
\hline 3 & 30.5 & 5.3 & 10.1 & 0.613 & 7.64 \\
\hline 4 & 30.1 & 5.5 & 10.5 & 0.510 & 7.65 \\
\hline 5 & 22.9 & 3.9 & 7.4 & 0.659 & 7.79 \\
\hline 6 & 44.9 & 7.7 & 14.6 & 0.643 & 7.30 \\
\hline 7 & 20.8 & 3.5 & 6.7 & 0.689 & 8.11 \\
\hline
\end{tabular}

$k_{2}$-ratio of the brine inclusion volume to the initial volume of the gas bubble; $P_{0}$ - initial pressure; $P_{\max }$ - maximum pressure; $R$ - universal gas constant; $T$ - temperature

gas, that pressure was proportional in the inclusions. At pressures of $0.47-0.58 \mathrm{MPa}$., a brine column thickness of 37-46 m corresponded to the pressure prevailing at the bottom of the salt basin.

\section{DISCUSSION}

Halite is a unique sedimentary mineral. Among the minerals found in sedimentary rocks, only in halite (and very rarely in

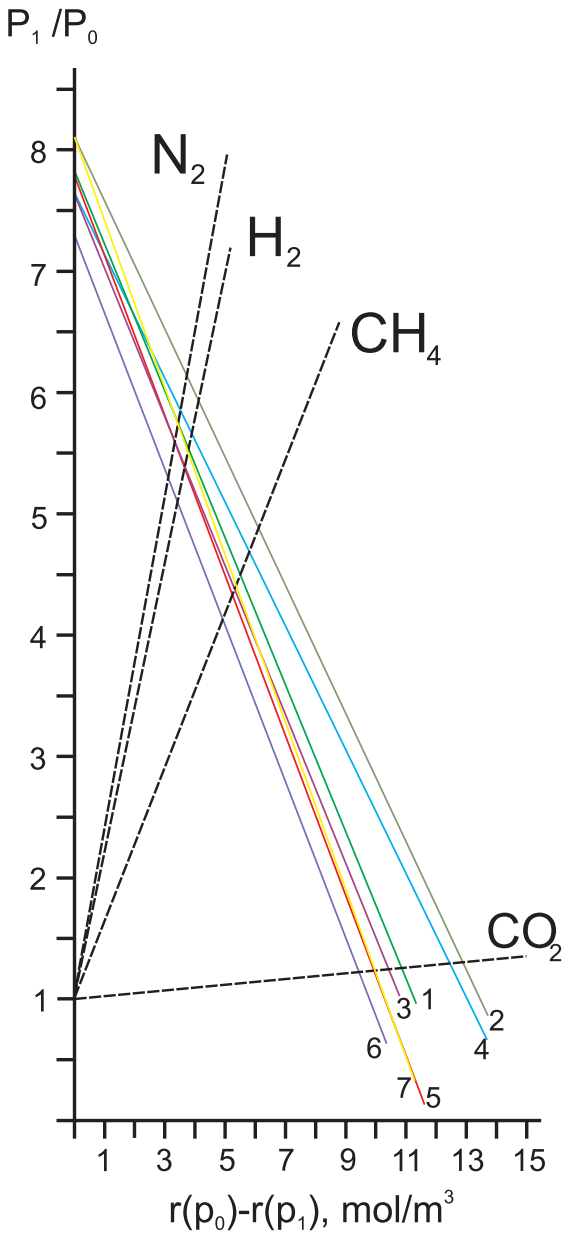

Fig. 5. Dependence of dissolvability of pure
gases on pressure

The long broken lines represent the solvability of these gases and are drawn according to Pavlov et al. (1987); the solid lines represent the numbers of inclusions based on the data from Table 2

sylvite) peculiar skeletal forms are established, which are uniquely identified as sedimentary crystalline textures. They contain numerous fluid inclusions, which are the conserved microdroplets of the brines of ancient saltwater basins (Kovalevych and Vovnyuk, 2010). The presence of rhythmic zonation in halite, manifested by inclusion-rich bands separated by clear halite bands without inclusions, caused by temperature fluctuations forming during the day, is typical for shallow salt basins. However, the types of chevron structure zonation can be related to various physicochemical conditions of halite crystallization and zonation did not always indicate the depth of basin (after Petrichenko, 1988). In the present study, halite samples did not represent typical rhythmic chevron zonation, but there was non-systematic zonation with rather poorly displayed rhythms (Fig. 3).

Our conclusions are based on the results of a study of superheated fluid inclusions in halite, from a depth more than $2.5 \mathrm{~km}$, and thus without conclusive evidence of the reliability of the results obtained, these results cannot be considered valid. The question of the correspondence of the physicochemical data obtained from the study of fluid inclusions in halite to the conditions of the salt formation still remains controversial. The reason for this is the high plasticity and solubility of halite, for 
Partial (reduced to standard) gas pressure when gas contained only $\mathrm{N}_{2}, \mathrm{CH}_{4}, \mathrm{CO}_{2}$, and $\mathrm{H}_{2}$

\begin{tabular}{|c|c|c|c|c|}
\hline \multirow{2}{*}{$\begin{array}{c}\text { No, of lines } \\
\text { (inclusions) }\end{array}$} & \multicolumn{4}{|c|}{ Initial / standard pressure $P_{1} / P_{0}[\mathrm{MPa}]$} \\
\cline { 2 - 5 } & $\mathrm{N}_{2}$ & $\mathrm{CH}_{4}$ & $\mathrm{CO}_{2}$ & $\mathrm{H}_{2}$ \\
\hline 1 & 0.59 & 0.46 & 0.15 & 0.56 \\
\hline 2 & 0.63 & 0.50 & 0.13 & 0.61 \\
\hline 6 & 0.54 & 0.43 & 0.12 & 0.52 \\
\hline
\end{tabular}

T a ble 4

Various gas mixtures in brines of the primary inclusions in halite

\begin{tabular}{|c|c|c|c|c|}
\hline \multirow{2}{*}{$\begin{array}{c}\text { Gas mixture } \\
\text { options }\end{array}$} & \multicolumn{4}{|c|}{ Content amount $\mathrm{N}_{i}[$ vol.\%] } \\
\cline { 2 - 5 } & $\mathrm{N}_{2}$ & $\mathrm{CH}_{4}$ & $\mathrm{CO}_{2}$ & $\mathrm{H}_{2}$ \\
\hline $\mathrm{A}$ & 75 & 16 & 5 & 4 \\
\hline $\mathrm{B}$ & 5 & 93 & 1 & 1 \\
\hline $\mathrm{C}$ & 56 & 32 & 8 & 4 \\
\hline $\mathrm{D}$ & 95 & 4 & 0.5 & 0.5 \\
\hline
\end{tabular}

which a change in temperature or pressure in the salt column can lead to the development of such processes as stretching and the migration or destruction of previously arisen fluid inclusions (Holdoway, 1974; Roedder, 1984). However, the limits of permissible changes in P-T conditions at which fluid inclusions in halite retain their information content are still poorly studied.

Many physical and chemical observations (Petrichenko, 1973, 1988; Bukowski et al., 2000; Galamay et al., 2003; Galamay and Bukowski, 2011; Meng et al., 2014) suggest that, after exposure of halite containing initially liquid inclusions, at temperatures ranging from 50 to $110^{\circ} \mathrm{C}$ and with increased pressure, the informative value of primary inclusions in halite may be preserved. The gas phase can appear due to stretching or partial cracking in inclusions after heating to $>50^{\circ} \mathrm{C}$ (Roedder, 1984), and the homogenization temperature of such inclusions corresponds to the temperature of salt deposit overheating (Petrichenko, 1973). The integrity of early diagenetic inclusions with the primary fluid inclusions in the Majiagou Formation halite have been preserved. This indicates that they are of the same chemical composition, and that the secondary fluid inclusions have a different composition (Meng et al., 2018).

The brine depth during the deposition of Ordovician evaporites in the Ordos Basin has been the subject of much controversy (Xue, 1986; Zhang et al., 1991; Bao et al., 2004). The lithology and the variation in facies and sedimentary structures of the evaporites clearly show that those of the 5th member of the Majiagou Formation formed in a marine epicontinental basin, in which the facies distributions are similar to a bull's eye pattern, with rock salts in the center of the basin (Xue, 1986). There are two contrasting models for the sedimentary facies of the Ordovician evaporites in the Ordos Basin. One is a classic carbonate platform model (Yao et al., 2008), and the other is a carbonate ramp model (Hou et al., 2002). According to Chen et al. (2019), during sea level lowstands, the water depth of the inner epeiric lagoon was less than the depth of the normal sea water, thereby resulting in a higher salinity water
Partial pressure (reduced to standard) of various gas mixtures

\begin{tabular}{|c|c|c|c|c|}
\hline \multirow{2}{*}{$\begin{array}{c}\text { No. of lines } \\
\text { (inclusions) }\end{array}$} & \multicolumn{4}{|c|}{$P_{1} / P_{0}=\Sigma\left(P_{1} / P_{0}\right)_{i} \mathrm{~N}_{i} / 100 \%[\mathrm{MPa}]$} \\
\cline { 2 - 5 } & $\mathrm{A}$ & $\mathrm{B}$ & $\mathrm{C}$ & $\mathrm{D}$ \\
\hline 1 & 0.55 & 0.46 & 0.51 & 0.58 \\
\hline 2 & 0.58 & 0.50 & 0.51 & 0.62 \\
\hline 6 & 0.49 & 0.43 & 0.47 & 0.53 \\
\hline Mean & 0.54 & 0.47 & 0.49 & 0.58 \\
\hline
\end{tabular}

body with an increasing salinity gradient toward its centre. In this high-salinity central lagoon, with occasionally stratified brine, the precipitation of halite crystals and the deposition of a large amount of thickly bedded rock salt occurred (Fig. 6). During highstands, when connections to the external ocean increased, the inner epeiric lagoon was dominated by the sedimentation of carbonate rocks with scarce evaporites.

In the boreholes below the salt deposits, there are mainly marine limestones (Fig. 2) created during sea level highstand. Above the salt deposits, there are dolomites with shallow-water depositional features, such as erosional surfaces and breccia. Therefore, Zhang et al. (1991) concluded that in the beginning, halite was formed in a deep basin, and then the evaporitic basin gradually shallowed to a sabkha environment. Macroscopic observations of the salt types and distributional patterns of the microfacies (Bao et al., 2004) support such variability. The origin of the various colours of evaporites is associated with the depth and environment of salt sedimentation, where dark halite is found in the lower parts of cores and changes into white halite in the middle parts, and finally into red halite containing high potassium contents in the upper parts of the cores. The halite investigated comes from the lower part of the Ma- 5 section, which was deposited when the evaporitic basin was still relatively deep ( 40 m), as shown in previous studies (Zhang et al., 1991; Bao et al., 2004).

Our research indicates the possibility of using a method of mathematical calculations to estimate the depth of the basin. These studies were carried out on selected samples with inclusions larger than 10-15 $\mu \mathrm{m}$, suitable for research under optical microscopy. We do not have enough data from other sections of the Majiagou Formation (Fig. 2) to determine the potential changes in the depth of the Ordos Basin.

Such depth changes were recorded for example in the Devonian Pripyat Basin (Petrichenko, 1988). The calculated depth of that basin was 22-30 $\mathrm{m}$ at the beginning of halite sedimentation, while after the sedimentation of a $250 \mathrm{~m}$ thick rock salt succession, the calculated depth decreased to 8-10 m. In the Permian Dnieper-Donetsk Basin, the calculated basin depth gradually changed from $13-15 \mathrm{~m}$ to $50 \mathrm{~m}$ during the sedimentation of a 40 m rock salt layer. In the upper part of the profile, halite deposition was abruptly replaced by the sedimentation of calcium sulphates, and the calculated depth reached 50-55 m (Petrichenko, 1988).

\section{CONCLUSIONS}

Studies of two-phase inclusions (liquid + gas) in halites from ancient marine salt-bearing formations make it possible to calculate the depth of the salt basin. However, such research 


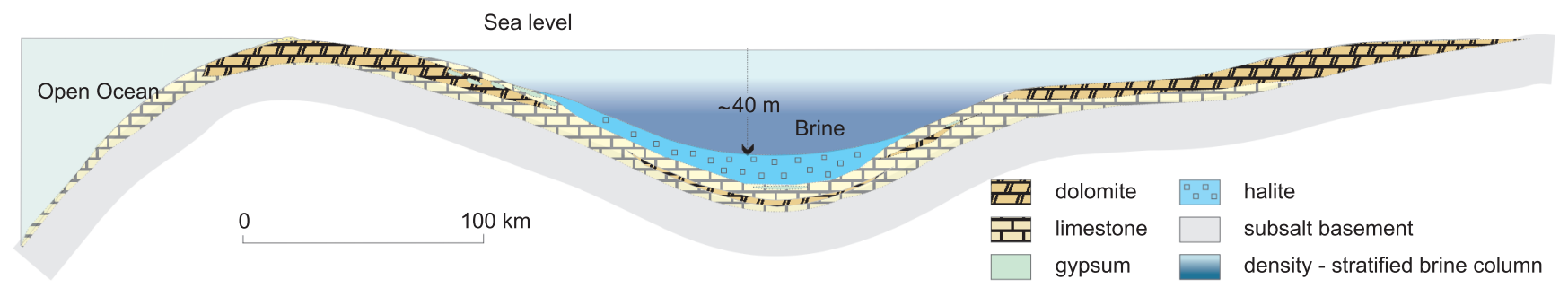

Fig. 6. Model of the Ordovician evaporite basin at the stage of halite sedimentation

should be preceded by identification genetic types of inclusions. Only fluid inclusions for which the chemical composition of brines was unchanged due to depressurization during their stretching or partial cracking are suitable for calculating basin depth.

The salt deposits of the Majiagou Formation during the post-sedimentation stages were overheated at temperatures of $62-70^{\circ} \mathrm{C}$. The coarse, late-diagenetic fluid inclusions of the recrystallized halite were depressurized under such conditions and overfilled at an elevated pressure. Meanwhile, the primary inclusions retained their integrity.

Slightly higher pressure of gas (relative to the atmospheric pressure) in the primary inclusions of bottom-grown halite crystals indicates a brine column thickness of $\sim 40 \mathrm{~m}$.
Our findings also support previous conclusions regarding the sedimentation model of the Ordovician Majiagou Formation based on petrological and sedimentary studies (Zhang et al., 1991; Bao et al., 2004; Chen et al., 2019).

Acknowledgements. This research was supported by the National Natural Science Foundation of China (Grant No. 41561144009) and the Natural Science Foundation of Jiangsu Province (Grant No.: BK20151611) and Basic Frontier Scientific Research Program of the Chinese Academy of Sciences (No. ZDBS-LY-DQC021). We also sincerely thank J. Szczepański, T. Peryt, and an anonymous reviewer for their comments and suggestions which improved the text.

\section{REFERENCES}

Acros, D., Ayora, C., 1997. The use of fluid inclusions in halite as environmental thermometer: an experimental study. In: European Current Research on Fluid Inclusions Biennial Symposium: 10-11.

Bao, H., Yang, C., Huang, J., 2004. "Evaporation drying" and "reinfluxing and redissolving"- a new hypothesis concerning formation of the Ordovician evaporites in eastern Ordos Basin (in Chinese with English summary). Journal of Palaeogeography, 6: $279-288$

Babel, M., 2007. Depositional environments of a salina-type evaporite basin recorded in the Badenian gypsum facies in northern Carpathian Foredeep. Geological Society, London, Special Publications, 285: 107-142.

Bąbel, M., Schreiber, B.C., 2014. Geochemistry of evaporites and evolution of seawater, In: Treatise on Geochemistry (2nd ed.), vol. 9 (ed. F. Mackenzie): 484-548. Sediments, Diagenesis, and Sedimentary rocks, Elsevier.

Borchert, H., Muir, R.O., 1964. Salt Deposits: the Origin, Metamorphism and Deformation of Evaporites: Van Nostrand Co., Ltd.

Bukowski, K., Galamay, A.R., Goralski, M., 2000. Inclusion brine chemistry of the Badenian salt from Wieliczka. Journal of Geochemical Exploration, 69: 87-90.

Chen, A., Yang, S., Xu, S., Ogg, J., Chen, H., Zhong, Y., Zhang, C., Li, F., 2019. Sedimentary model of marine evaporites and implications for potash deposits exploration in China. Carbonates and Evaporites, 34: 83-99.

Feng, Z., Zhang, Y., Jin, Z., 1998. Type, origin, and reservoir characteristics of dolostones of the Ordovician Majiagou Group, Ordos, North China platform. Sedimentary Geology, 118: 127-140.
Galamay, A.R., Baranenko, O.V., 2004. Hydrocarbons in the Badenian salts of the Fore-Carpathian and Transcarpathian regions (in Ukrainian). Mineralogical Review, 54: 132-136.

Galamay, A.R., Bukowski, K., 2011. Chemical composition of Badenian brines from primary fluid inclusions in halite (Transcarpathian Basin, Ukraine) (in Polish with English summary). Geology, Geophysics and Environment, 37: 245-267.

Galamay, A.R., Bukowski, K., Czapowski, G., 2003. Chemical composition of brine inclusions in halite from clayeysalt (zuber) facies from the Upper Tertiary (Miocene) evaporite basin (Poland). Journal of Geochemical Exploration, 78-79: 509-511.

Galamay, A.R., Bukowski, K., Poberezhskyy, A.V., Karoli, S., Kovalevych, V.M., 2004. Origin of the Badenian salts from East Slovakian Basin indicated by the analysis of fluid inclusions. Annales Societatis Geologorum Poloniae, 74: 267-276.

Holdoway, K.A., 1974. Behavior of fluid inclusions in salt during heating and irradiation. Northern Ohio Geological Society, 1: 303-312.

Hou, F.H., Fang, S.X., Zhao, J.S., Dong, Z.X., Li, L., Wu, Y., Chen, Y.N., 2002. Depositional environment model of Middle Ordovician Majiagou Formation in Ordos Basin (in Chinese with English summary). Marine Origin Petroleum Geology, 7: 38-46.

Ivanov, A.A., Voronova, M.L., 1972. Halogenic Formations: Mineral Composition, Types, and Formation Environments (Methods of the Prospecting and Exploration of Mineral Salt Deposits) (in Russian). Nedra.

Kalyuzhny, V.A., 1982. The Foundations of Teaching about Mineral-forming Fluids (in Russian). Naukova Dumka, Kyiv.

Kovalevych, V.M., Vovnyuk, S.V., 2010. Fluid inclusions in halite from marine salt deposits: are they real micro-droplets of ancient seawater? Geological Quarterly, 54 (4): 401-410. 
Kovalevich, V.M., Jarmołowicz-Szulc, K., Peryt, T.M., Poberegski, A.V., 1997. Messinian chevron halite from the Red Sea (DSDP Sites 225 and 227): fluid inclusion study. Neues Jahrbuch für Mineralogie Monatshefte, 10: 433-450.

Kovalevych, V.M., Peryt, T.M., Zang, W., Vovnyuk, S.V., 2006. Composition of brines in halite-hosted fluid inclusions in the Upper Ordovician, Canning Basin, Western Australia: New data on seawater chemistry. Terra Nova, 18: 95-103.

Kovalevych, V.M., Peryt, T.M., Shanina, S.N., Wieclaw, D., Lytvyniuk, S.F., 2008. Geochemical aureoles around oil and gas accumulation in the Zechstein (Upper Permian) of Poland: Analysis of fluid inclusions in halite and bitumens in rock salt. Journal of Petroleum Geology, 31: 245-262.

Kovalevych, V.M., Paul, J., Peryt, T.M., 2009. Fluid inclusions in halite from the Röt (Lower Triassic) salt deposit in Central Germany: evidence for seawater chemistry and conditions of salt deposition and recrystallization. Carbonates and Evaporites, 24: 45-57.

Li, R.X., Guzmics, T., Liu, X.J., Xie, G.C., 2011. Migration of immiscible hydrocarbons recorded in calcite-hosted fluid inclusions, Ordos Basin: a case study from Northern China. Russian Geology and Geophysics, 52: 1491-1503.

Litvinyuk, S.F., 2007. Geochemical halos in salts over hydrocarbon deposits (according to the results of the study of inclusions in halite) (in Ukrainian with English summary). Geology and Geochemistry of Minerals, 4: 95-111.

Lowenstein, T.K., Hardie, L.A., 1985. Criteria for the recognition of salt-pan evaporites. Sedimentology, 32: 627-644.

Matukhin, R.G., Petrichenko, O.Y., Sokolov, P.N., 1985. Gas-liquid inclusions in halite as an indicator of the formation conditions of the Devonian salt-bearing sediments of Siberia (in Russian). In: Lithologic-facies and Geochemical Problems of Salt Accumulation (ed. A.L. Yanshin): 194-203. Nauka.

Meng, F-W., Galamay, A.R., Yang, C-H., Li, Y-P., Zhuo, Q-G., 2014. The major composition of a middle-late Eocene salt lake in the Yunying depression of Jianghan Basin of Middle China based on analyses of fluid inclusions in halite. Journal of Asian Earth Sciences, 85: 97-105.

Meng, F., Zhang, Y., Galamay, A.R., Bukowski, K., Ni, P., Xing, E., Ji, L., 2018. Ordovician seawater composition: evidence from fluid inclusions in halite. Geological Quarterly, 62 (2): 344-352.

Meng, F-W., Zhang, Z-L., Yan, X-Q., Ni, P., Liu, W-H., Fan, F., Xie, G-W., 2019. Stromatolites in Middle Ordovician carbonate-evaporite sequences and their carbon and sulfur isotopes stratigraphy, Ordos Basin, northwestern China. Carbonates and Evaporites, 34: 11-20.

Moskovskyi, G.A., 1983. Research of physical and chemical sedimentation conditions of the Kungurian salt sediments of the western part of the Caspian syncline based on inclusions in minerals (in Russian). Ph.D. thesis, Moscow University.

Petrichenko, O.I., 1973. Methods of study of inclusions in minerals of saline deposits (in Ukrainian). Fluid Inclusion Research, 12: 214-274.

Petrichenko, O.I., 1988. Physico-chemical conditions in the sedimentation of the ancient halogen basins (in Russian). Naukova Dumka.
Roedder, E., 1984. Fluid inclusions In: Reviews in Mineralogy 12. Mineralogical Society of America.

Schmalz, R.F., 1969. Deep-water evaporite deposition: a genetic model. AAPG Bulletin, 53: 798-823.

Scotese, C.R., 2014. Atlas of Silurian and Middle-Late Ordovician Paleogeographic Maps (Mollweide Projection), Maps 73-80 (vol. 5): The Early Paleozoic. PALEOMAP Atlas for ArcGIS, PALEOMAP Project.

Strakhov, N.M., 1967. Principles of Lithogenesis. New York. Springer.

Wang, B.Q., Al-Aasm, I.S., 2002. Karst-controlled diagenesis and reservoir development: example from the Ordovician mainreservoir carbonate rocks on the eastern margin of the Ordos basin, China. AAPG Bulletin, 86: 1639-1658.

Weiss, R.F., 1969. Dissolved argon, nitrogen and total carbonate in the Red Sea brines. In: Hot Brines and Recent Heavy Metal Deposits in the Red Sea: a Geochemical and Geophysical Account (eds. E.T. Degens and D.A. Ross): 254-260. Springer-Verlag.

Więcław, D., Lytvyniuk, S.F., Kovalevych, V.M., Peryt, T.M., 2008. Fluid inclusions in halite and bitumens in rock salt from Miocene evaporites in the Ukrainian Fore-Carpathian region: as indicators of hydrocarbon accumulations in the underlying strata (in Polish with English summary). Przegląd Geologiczny, 56: 837-841.

Valyashko, M.G., 1952. Halite, its principal varieties found in salt lakes and its structural features (in Russian). Proceedings of the All-Union Institute of Halurgy, 23: 25-53.

Valyashko, M.G., 1962. The principle of forming of salt deposits (in Russian). Moscow, MGU.

Xue, P., 1986. Origin of evaporites in a vast epicontinental platform sea (in Chinese with English summary). Geological Review, 32: 59-66.

Yang, Y., Li, W., Ma, L., 2005. Tectonic and stratigraphic controls of hydrocarbon systems in the Ordos basin: a multicycle cratonic basin in central China. AAPG Bulletin, 89: 255-269.

Yao, J-L., Zhao, Y-G., Lei, B-J., Hao, H-Y., 2008. Sequence lithofacies paleogeography of western Ordos Basin in Majiagou Stage (in Chinese with English summary). Journal of Southwest Petroleum University, 30: 33-37.

Yu, Q., Ren, Z., Li, R., Wang, B., Qin, X., Tao, N., 2017. Paleogeotemperature and maturity evolutionary history of the source rocks in the Ordos Basin. Geological Journal, 52: 97-118.

Zhang, J., Zeng, S., Huang, J., Ma, Z., Wang, Z., 1991. The occurrence and significance of halite in Eastern Ordos (in Chinese with English summary). Acta Sedimentologica Sinica, 9: 34-43.

Zhang, F., Li, J., Wei, G., Liu, X., Guo, J., Li, J., Fan, L., She, Y., Guan, H., Yang, S., Shao, L., 2018. Formation mechanism of tight sandstone gas in areas of low hydrocarbon generation intensity: a case study of the Upper Paleozoic in north Tianhuan depression in Ordos Basin, NW China. Petroleum Exploration and Development, 45: 79-87.

Zhukhovitsky, A.A., Shvartsman, L.A., 1968. Physical Chemistry (in Russian). Metallurgy, Moscow. 